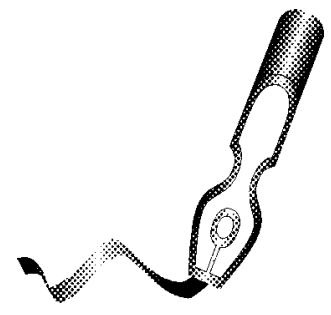

\title{
Sociedad Chilena Otorrinolaringología, Medicina y Cirugía Cabeza y Cuello
}

En el mes de junio del presente año se cumplieron 75 años desde la fundación de nuestra Sociedad Chilena de Otorrinolaringología, Medicina y Grugía de Cabeza y Ouello, que fue creada el año 1931 por la iniciativa e impulso de un grupo de 20 médicos visionarios, liderados por el Dr. Alejandro del Río Soto-Aguilar, que se había formado como especialista en Francia y Alemania. En el mes de agosto del mismo año, se formó el primer directorio de la institución.

日 Dr. Del Río fue un gran personaje de la medicina y del país en su época, participando en la renovación de varias instituciones asistenciales. Fue un gran impulsor de la Medicina Social, cuyo desarrollo en los comienzos del siglo XX, es uno de los hitos destacados de la Historia de la Medicina Chilena Ocupó entre muchos otros cargos el de Ministro de Salud. contexto político, económico y social en el momento en que nace nuestra Sociedad era extremadamente complicado dentro y fuera del país. La década de los treinta se inició con la gran depresión que marcó el derrumbe de la economía mundial, masificó la cesantía y terminó en Chile con la era de prosperidad que se había iniciado con el auge del salitre. Este período traería consigo profundos cambios a nivel nacional e internacional, que se manifestarían en nuestro país por crisis económicas, movimientos sociales y anarquía política acompañadas de un gran terremoto, que terminaría por cambiar incluso la geografía del país.

Nuestra Sociedad, entonces nace en una época de crisis, en pleno auge de la Medicina Social, liderada por un médico que se destacó en variados ámbitos de la medicina y organización del sistema público de salud, por lo que deberíamos entender que el origen de la Sociedad buscó organizar una naciente especialidad, en un contexto en el que estaba llamada a jugar un rol destacado en el sistema de salud del país, que hoy estamos llamados a rescatar para situar a la especialidad y nuestra Sociedad en un sitial destacado, en la medicina y en la comunidad nacional.

Indudablemente, que no sólo los orígenes son importantes, sino que también como se ha desarrollado la Sociedad desde el hito fundacional hasta nuestros días. Tenemos que reconocer en este lapso de tiempo de 75 años, a muchos pioneros, su entrega, abnegación y sentido del deber, que han sido el pilar fundamental de nuestra consolidación y desarrollo como especialidad y como institución. Sabemos que la generación del 40 fue la que dio origen a los hitos más emblemáticos de nuestra historia como la revista, el CEEE y las jornadas de 
Valparaíso que es el actual congreso chileno. Con posterioridad muchos maestros destacados nos entregaron los fundamentos de lo que somos hoy.

Sin duda que somos herederos de una rica tradición que debemos ser capaces de valorar, para transmitir a las nuevas generaciones los conceptos que han inspirado el quehacer de la especialidad, desde sus inicios hasta nuestros días.

Sin embargo, esta mirada hacia el pasado, más allá que evocar recuerdos importantes de nuestra historia, debe ser la base de una mirada hacia el futuro en que seamos capaces de ampliar el horizonte del desarrollo de la especialidad planteándonos metas, cuyo cumplimiento nos permitan ser un mejor aporte a la salud del país, así como tener una creciente inserción en el ámbito internacional.

Dr. David Jofré Pavez

Presidente

Sociedad Chilena de Otorrinolaringología, Medicina y Grugía de Cabeza y Cuello 